\title{
Investigation of Antioxidant Activities and Hypoglycemic Effect of Black and White Myrtle Fruits
}

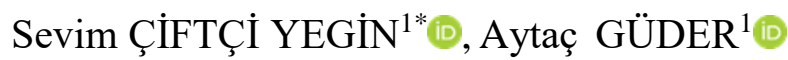 \\ ${ }^{1}$ Giresun University, Health Service Vocational School of Higher Education, Giresun- Turkey
}

Geliş / Received: 02/10/2020, Kabul / Accepted: 29/03/2021

\begin{abstract}
Fruits, are in black or white colour Mrytus communis, is known as locally name murt, hambales, mersin. It is an aromatic and medicinal plant that grows naturally in maquis form in regions with Mediterranean climate. In this research, we aimed to investigate the hypoglycemic effect and antioxidant activity of Myrtus communis L. White-black myrtle were collected from Hassa-Hatay and Tarsus-Mersin, respectively in October. Fruits were separated from the leaves and dried in the oven at $40^{\circ} \mathrm{C}$. Fruit extracts were obtained in absolute ethanol $(1: 15)$ by using magnetic stirrer at the room temperature for one day. In this study, radical scaving activity-(DPPH), the hydrogen peroxide scavenging activity-(HPSA), metal chelating activity-(MCA), ferric reducing antioxidant power activity-(FRAP), total phenol-flavonoid contents and $\alpha$-amylase, $\alpha$-glycosidase inhibition were examined to determine characteristics of samples. DPPH and HPSA values were expressed as $\mu \mathrm{g} / \mathrm{ml}$ in terms of $\mathrm{SC}_{50}$. FRAP and MCA features of extract were given as \% activity. The hypoglycemic effect was investigated with $\alpha$-amylase, $\alpha$-glucosidase inhibition assays. The DPPH, HPSA, FRAP, MCA of white-black myrtle samples were found $56.75-63.52 \mu \mathrm{g} / \mathrm{ml}, 193.95-207.73 \mu \mathrm{g} / \mathrm{ml}, 81.68-90.87 \%$, and $20.88-27.71 \%$, respectively. When the antioxidant results compare with the used standards such as Buthylated-Hydroxy-Anisole, Rutin, Trolox, white-black myrtle samples have effective antioxidant activity. Samples have shown hypoglycemic effect.
\end{abstract}

Keywords: Antioxidant activities, Hypoglycemic effect, Myrtus communis L.

Siyah ve Beyaz Murtların Hipoglisemik Etkisi ve Antioksidan Aktivitesinin Araştırılması

Latincesi Myrtus communis L. olan halk arasında murt, hambeles, mersin diye adlandirılan meyve siyah veya beyaz renkte olmaktadır. Tıbbi ve aromatik bir bitki olan mersin, akdeniz ikliminin yaygın olduğu bölgelerde doğal olarak yetişir. Bu çalışmada, Myrtus communis L. nin antioksidan aktivitesini ve hipoglisemik etkisini belirlemek amaçlanmıştır.

Beyaz ve siyah mersin örnekleri sırayla Hassa-Hatay ve Tarsus-Mersin den hasat dönemi olan Ekim ayında toplanmıştır. Meyveler yapraklarından ayrılarak etüvde $40^{\circ} \mathrm{C}$ de kurutuldu. Kuru örnekler toz haline getirilerek, absolute etanol (1:15) ile 1 gün boyunca manyetik karıştırıcıda karıştırılıp, süzgeç kağıdı ile süzülerek örneklerin özütü elde edildi.

$\mathrm{Bu}$ çalışmada Radikal giderme aktivitesi (DPPH), Hidrojen peroksit giderme aktivitesi (HPSA), Demir indirgeme kapasitesi (FRAP) ve Metal şelat oluşturma aktivitesi (MŞA), Total feneol-flavonoid içerikleri ile hipoglisemik etki için $\alpha$-amilaz, $\alpha$-glikozidaz inhibisyonu araştırıldı. DPPH ve HPSA değerleri $\mathrm{SC}_{50}$ ile FRAP ve MŞA ise \% olarak ifade edildi. Hipoglisemik etki ise $\alpha$-amilaz, $\alpha$-glikozidaz inhibisyonu ölçümü ile belirlendi. Beyaz ve siyah murt örneklerinde DPPH, HPSA, FRAP, MŞA değerleri sırasıyla 56.75-63.52 $\mu \mathrm{g} / \mathrm{ml}$, 193.95-207.73 $\mu \mathrm{g} / \mathrm{ml}, 81.68-90.87 \%$, 20.88-27.71\% bulunmuştur. Antioksidan sonuçlar Bütilat Hidroksi Anisol (BHA), Rutin (RUT) ve Trolox (TRO) gibi standartlarla karşılaştırıldığında beyaz ve siyah murt örnekleri etkili bir antioksidan aktivite göstermiştir. Örnekler aynı zamanda etkili bir hipoglisemik etki göstermiştir.

*Corresponding Author: sevimbio@gmail.com 
Anahtar Kelimeler: Antioksidan aktivite, Hipoglisemik etki, Myrtus communis L.

\section{Introduction}

Myrtus communis is scientific name of Myrtle which capaciously used as a medicinal plant and herbal medicine. At the same time, it is cultivated as an ornamental plant for use as a shrub in gardens and parks (Baharvand et al., 2015).

Phenolic substances are usually metabolites in different structures and functions, having an aromatic ring. Also, this aromatic ring contains one or more hydroxyl groups (Naczk and Shadidi, 2004). Polyphenols and flavonoids in plant show efficient antioxidant properties due to their high redox potentials (Tsao and Yang, 2003). Myrtle is traditionally consumed as antidiabetic agent among the public (Sepici Dincel et al., 2004). It is indicated that myrtle leaf extract had antihyperglycemic and antibacterial properties in the literature. Recently, antioxidant properties of different myrtle extracts and certain ingredients have been described. In addition, Jahori et al., (2014) and Ferchichi et al., (2011) noted the use as a medicament for the treatment of diseases associated with oxidative stress, including diabetes mellitus.

$\alpha$-amylase, which is the main enzyme, is responsible for the breakdown of starch into simpler sugars (Alexander, 1992; Davies and Henrissat, 1995). Although the activity of the enzyme was directly incorporated into the etiology of diabetes, it increased glucose tolerance in which $\alpha$-amylase inhibitors were diabetic patients (Lebovit, 1998).

In the recent years, diabetes is a metabolic disease that is widely seen and reduces the quality of life. Studies on plants traditionally used among the people are carried out continuously. Particularly, it are carried out different studies of the plants used against diabetes (Durmuş et al., 2016; Karaman and Elgin Cebe, 2016).

The purpose of this research is to investigate the hypoglycemic effect and antioxidant activity of black and white myrtle.

\section{Material and Methods}

The samples used in this study were obtained from Hassa-Hatay and Tarsus-Mersin regions in Turkey. Myrtle samples were gathered in harvest period (October).

In this study, 2 different myrtle fruits were used as black myrtle, white myrtle. Samples were dried in drying oven at $40^{\circ} \mathrm{C}, 96$ hours. Dried samples were extracted with absolute ethanol by using a magnettic stirrer.

\subsection{Antioxidant activities}

\subsubsection{Free radical scavenging activity assay (DPPH)}

DPPH free radical scavenging activities of myrtle samples were carried out according to literature method (Blois, 1958). In this assay, $1.0 \mathrm{~mL}$ of $\mathrm{DPPH}^{\circ}$ (prepared in absolute ethanol as $0.1 \mathrm{mM}$ ) and $3.0 \mathrm{~mL}$ of sample solution was added and stirred. It was stand up at the room temperature in a dark setting during $30 \mathrm{~min}$. Samples/standards absorbances were recorded at $517 \mathrm{~nm}$. The obtained values were expressed as $\mathrm{SC}_{50}$ ( $\mu \mathrm{g} / \mathrm{mL})$.

\subsubsection{Hydrogen peroxide scavenging activity assay (HPSA)}

The hydrogen peroxide scavenging activities were examined in reference to Ruch method (Ruch et al., 1989). In this assays, sample (3.4 $\mathrm{mL}$ ) and $0.6 \mathrm{~mL}$ of $\mathrm{H}_{2} \mathrm{O}_{2}$ (prepared with $\mathrm{pH}=7.4$ and $0.04 \mathrm{M}$ phosphate buffer as 40 
$\mathrm{mM}$ ) was mixed during $10 \mathrm{~min}$. The final mixtures' absorbance values was recorded at $230 \mathrm{~nm}$. For this reason, phosphate buffer was used as a blank sample. The obtained results were stated as $\mathrm{SC}_{50}$ values $(\mu \mathrm{g} / \mathrm{mL})$.

\subsubsection{Ferric reducing antioxidant power assay (FRAP)}

Ferric reducing antioxidant activities were investigated by using Oyaizu method (Oyaizu, 1986). For this reason, $2.5 \mathrm{~mL}$ of PBS (pH 6.6, $0.2 \mathrm{~mol} \mathrm{~L}^{-1}$ ) and $2.5 \mathrm{~mL}$ of potassium ferricyanide $(1.0 \%)$ were added into samples/standards $(2.5 \mathrm{~mL})$ tubes, respectively. The final mix tubes were incubated at $50^{\circ} \mathrm{C}$ for $20 \mathrm{~min}$ and then $2.5 \mathrm{~mL}$ of TCA $(10 \%)$ were mixed with the all test and standard tubes. $2.5 \mathrm{~mL}$ of distilled water and $0.5 \mathrm{~mL}$ of $\mathrm{FeCl}_{3}(0.1 \%)$ were mixed with 2.5 $\mathrm{mL}$ of this solution. The FRAP was calculated with using the absorbance values at $700 \mathrm{~nm}$ following the formula:

$\operatorname{FRAP}(\%)=\left(A_{\triangleleft} / A_{c}\right) \times 100$

$A_{c}$ : Absorbance of control, $A_{s}$ : Absorbance of samples/standards

\subsubsection{Metal chelating activity assay (MCA)} The metal chelating activities of the standards/samples antioxidant materials were determined by following the Dinis Method (Dinis et al., 1994). The sample/standard solutions $(0.4 \mathrm{~mL})$ mixed with $\mathrm{FeCl}_{2}(0.05$ $\mathrm{mL}, 2 \mathrm{mM})$. The mixtures were kept during 10 min. $0.2 \mathrm{~mL}$ of ferrozine $(5 \mathrm{mM})$ and $3.3 \mathrm{~mL}$ of absolute ethanol were added to all test and standard tubes. The all tubes were forcefully shaken and the absorbance values of the samples were recorded at $562 \mathrm{~nm}$. The MCA were obtained by using this formula:

Ferrous Ions Chelating Activity (\%) $=[1-$ $\left.\left(A_{s} / A_{c}\right)\right] \times 100$

\subsubsection{Total phenolic content (TPC)}

The total phenolic content in the sample extract was investigated according to the Slinkard and Singleton by using FolinCiocalteu reagent (Silinkard and Singleton,
1977). $0.5 \mathrm{~mL}$ of standard/sample solution in ethyl alcohol $(1 \mathrm{mg} / \mathrm{mL})$ were mixed with 7.0 $\mathrm{mL}$ of deionized water. Then, $0.5 \mathrm{~mL}$ of Folin $\mathrm{C}$ reagent was added and all tubes were vortexed for $3 \mathrm{~min} .2 .0 \mathrm{~mL}$ of $\mathrm{Na}_{2} \mathrm{CO}_{3}(2.0 \%)$ was added and tubes were stand up at the room temperature in a dark environment during 2 hours. Absorbance values of tubes were recorded at $760 \mathrm{~nm}$. TPC of the sample was calculated by using gallic acid calibration curve $\left(\mathrm{R}^{2}: 0.9964\right)$.

\subsubsection{Total flavonoid content (TFC)}

Total flavonoid content of sample extract was carried out in reference to the literature method by using aluminium chloride (Chang et al., 2002). $0.5 \mathrm{~mL}$ of samples in ethyl alcohol $(1 \mathrm{mg} / \mathrm{mL})$ was combined with $1.5 \mathrm{~mL}$ of deionized water. Then, $0.1 \mathrm{~mL}$ of $\mathrm{A}_{1 \mathrm{C}} 1_{3} \cdot 6 \mathrm{H}_{2} \mathrm{O}(10.0 \%), 0.1 \mathrm{~mL}$ of potassium acetate $(1 \mathrm{~mL})$ and $2.8 \mathrm{~mL}$ of deionized water were added, respectively. All tubes were waited at room temperature during $30 \mathrm{~min}$. After this period, absorbance values were measured at $415 \mathrm{~nm}$. TFC of the sample was calculated by using catechin calibration curve $\left(\mathrm{R}^{2}=0.9970\right)$.

\subsection{Hypoglycemic effect}

\subsection{1. $\alpha$-amylase inhibition assay}

$\alpha$-amylase inhibition assay as in vitro was analyzed by following the Bernfeld method with minor modifications (Bernfeld, 1955; Guder, 2016). The starch (0.5\%) solution was obtained by boiling and blending potato starch $(0.25 \mathrm{~g})$ in deionized water $(50 \mathrm{~mL})$ for 15 min. The $\alpha$-amylase (EC 3.2.1.1) enzyme (0.5 unit $/ \mathrm{mL}$ ) solution was procured by blending $\alpha$-amylase $(0.001 \mathrm{~g})$ in phosphate buffer solution (PBS) (pH 6.9, $20 \mathrm{mM}, 100 \mathrm{~mL}$ ) containing $\mathrm{NaCl}$ (6.7 mM). Samples (5-100 $\mu \mathrm{g} / \mathrm{mL}$ ) and acarbose were dissolved at various concentrations in PBS. The solution of color reagent contains DNS $(20 \mathrm{~mL}, 96$ $\mathrm{mM})$, sodium potassium tartrate $(5.31 \mathrm{M}, 8$ $\mathrm{mL})$ in $\mathrm{NaOH}(2.0 \mathrm{M})$ and distilled water (12 
mL). $1 \mathrm{~mL}$ of samples (TAMC or acarbose) and $1.0 \mathrm{~mL}$ of enzyme solution were mixed and waited at $25^{\circ} \mathrm{C}$ for $30 \mathrm{~min} .1 .0 \mathrm{~mL}$ of starch solution was added with $1 \mathrm{~mL}$ of this mixture and incubated at $25^{\circ} \mathrm{C}$ during $3 \mathrm{~min}$. After this period, $1.0 \mathrm{~mL}$ of color reagent was added. The closed tubes were stand up in water bath (at $85^{\circ} \mathrm{C}$ ) during $15 \mathrm{~min}$. The cooled reaction mixtures were diluted with distilled water $(9.0 \mathrm{~mL})$ and the absorbance value was recorded at $540 \mathrm{~nm}$. IC 50 values were used for expression of $\alpha$-amylase inhibition activities. Linear regression analysis was used for the determination of $\mathrm{IC}_{50}$ values. For the blank tube, the color reagent solution was mixed with starch solution. This mixture was waited into the boiling water bath. The other procedures were performed as the test tube. Control tube was prepared with PBS (1.0 mL). Positive control (acarbose solution) was used for compared with the sample result.

\subsection{2. $\alpha$-glucosidase inhibition assay}

A previously described bioassay method was used for measurement $\alpha$-glucosidase inhibition of samples (McCue et al., 2005). The enzyme solution was prepared by using $20 \mu \mathrm{L}$ of $\alpha$-glucosidase (EC 3.2.1.20) enzyme (0.5 unit $/ \mathrm{mL}$ ) and $120 \mu \mathrm{L}$ of PBS (pH 6.9, 0.1 M). $\quad p$-nitrophenyl- $\alpha$-D-glucopyranoside as substrate solution was used $(5.0 \mathrm{mM}$ in the PBS). $10 \mu \mathrm{L}$ of acarbose and samples at different concentrations were dissolved in PBS $(5-100 \mu \mathrm{g} / \mathrm{mL})$. Enzyme solution was mixed with this solution and waited during 15 $\min$ at $37^{\circ} \mathrm{C}$. End of the incubation period, 20 $\mu \mathrm{L}$ of substrate solution was added and kept for at $37^{\circ} \mathrm{C}$ during $15 \mathrm{~min}$ again. The reaction was stopped with addition of $80 \mu \mathrm{L}$ of $\mathrm{NaCO}_{3}$ solution $(0.2 \mathrm{M})$. Enzyme inhibition values were measured via absorbance value at 405 $\mathrm{nm}$. IC 50 values were used for expression of $\alpha$ - glucosidase inhibition activities. Linear regression analysis was used for the determination of $\mathrm{IC}_{50}$ values.

\section{Research Findings}

Table 1. Antioxidant activities of Black and White Myrtle Samples and Standards

\begin{tabular}{|c|c|c|c|c|}
\hline & $\begin{array}{c}\text { Free } \\
\text { Radical } \\
\text { Scavenging } \\
\text { Activity- } \\
\text { DPPH } \\
\left(\text { SC }_{50}\right) \\
\end{array}$ & $\begin{array}{l}\text { HPSA } \\
\left(\text { SC }_{50}\right)\end{array}$ & $\begin{array}{c}\text { FRAP } \\
(\%)\end{array}$ & $\begin{array}{c}\text { Metal } \\
\text { chelating } \\
\text { activity- } \\
\text { MCA } \\
(\%)\end{array}$ \\
\hline $\begin{array}{l}\text { White } \\
\text { Myrtle }\end{array}$ & 56.75 & 193.95 & 81.68 & 20.88 \\
\hline $\begin{array}{l}\text { Black } \\
\text { Myrtle }\end{array}$ & 63.52 & 207.73 & 90.87 & 27.71 \\
\hline BHA & 18.56 & 8.76 & 94.19 & 93.11 \\
\hline RUTIN & 10.56 & 17.78 & 95.27 & 94.39 \\
\hline TROLOX & 190.51 & 26.46 & 86.46 & 88.58 \\
\hline
\end{tabular}

Table 2. Total Phenolic and Total Flavonoid Contents of Black and White Myrtle Samples

\begin{tabular}{lcc}
\hline Samples & $\begin{array}{c}\text { Total Phenolic } \\
\text { Content } \\
(\mathbf{m g ~ G A E} / \mathrm{g})\end{array}$ & $\begin{array}{c}\text { Total Flavonoid } \\
\text { Content } \\
(\mathbf{m g ~ C A E} / \mathrm{g})\end{array}$ \\
\hline White Myrtle & 682.25 & 212.34 \\
\hline Black Myrtle & 797.20 & 395.24
\end{tabular}

Table 3. Hypoglycemic effects $\left(\mathrm{IC}_{50}-\mu \mathrm{g} \mathrm{mL}{ }^{-1}\right)$ of Black and White Myrtle Samples and Acarbose

\begin{tabular}{|c|c|c|c|}
\hline Parameters & $\begin{array}{l}\text { White } \\
\text { Myrtle }\end{array}$ & $\begin{array}{c}\text { Black } \\
\text { Myrtle }\end{array}$ & Acarbose \\
\hline $\begin{array}{l}\alpha- \\
\text { Glucosidase } \\
\text { Inhibition } \\
\left(\mathbf{I C}_{50}-\mu \mathrm{g}\right. \\
\left.\mathbf{m L}^{-1}\right)\end{array}$ & 1603.61 & 1355.64 & 79.12 \\
\hline $\begin{array}{l}\text { a-Amylase } \\
\text { Inhibition } \\
\left(\mathrm{IC}_{50^{-}}-\mu \mathrm{g}\right. \\
\left.\mathrm{mL}^{-1}\right)\end{array}$ & 784.92 & 571.84 & 94.89 \\
\hline
\end{tabular}


4. Results

Ferric reducing antioxidant power, metal chelating activities, DPPH radical scavenging activities and hydrogen peroxide scavenging activities of standards and samples are found at the intervals of $10.56-190.51 \mu \mathrm{g} / \mathrm{mL}, 8.76$ $-207.73 \mu \mathrm{g} / \mathrm{mL}, 81.68-95.27 \%$ and $20.88-$ $94.39 \%$, respectively (Table 1). According to obtained results, DPPH radical scavenging activities of samples are higher than Trolox. HPSA results of samples are not as effective as standards. FRAP activities of Black Myrtle are more efficient than Trolox. Metal chelating activities of samples are not as well as standards. We can say that black myrtle exhibits more effective antioxidant activity than white myrtle. On the other hand, comparing DPPH radical scavenging activity and FRAP, black myrtle showed more activity than trolox. Also, BHA and RUT have a higher value than the standard in all activities examined. Methanol extract of myrtle fruit supplied from Mediterranean region of Turkey has the influential of radical scavenging and antioxidant activity (Asif et al., 2011). Radical scavenging activity of the essential oil of myrtle flowers from Morocco was the highest level at $200 \mu \mathrm{g} / \mathrm{ml}$ of concentration. This essential oil containing mainly monoterpene hydrocarbons and their derivatives are known to possess good antioxidant activity (Derwick et al., 2011). Moreover, the essential oil obtained from $M$. communis leaves has the effective DPPH radical scavenging activity (Mimika-Dukic et al., 2010). Trolox equivalent antioxidant capacity analyzes indicated that the black $M$. communis berries has the high radical scavenging activities. This effective activity may be due to its rich flavonoids and anthocyanin content (Montoro et al., 2006).

Total flavonoid and phenolic contents of samples were stated as $\mathrm{mg} \mathrm{GAE} / \mathrm{g}$ and $\mathrm{mg}$
$\mathrm{CAE} / \mathrm{g}$, respectively. In reference to obtained results, black myrtle sample has exhibited higher total phenolic and flavonoid contents than white myrtle sample (Table 2). Antioxidant activities of plant extracts are related to their phenolic content (Wang et al., 1999). Flavonoids and anthocyanins are essential components in the myrtle fruits and extracts. The phenolic content and essential oil of some species such as P. lentiscus L. and M. communis L. in Zakynthos (Greece) were determined. The effective antioxidant properties of both plants indicate that they are rich in phenolic contents (Chyssavgi et al., 2008).

In vitro hipoglycemic effect were applied for determination samples $\alpha$-glucosidase and $\alpha$ amylase inhibition activity assays. Acarbose was used as control. White and black myrtle samples show lower hypoglycemic effect than acorbose. $\alpha$-glucosidase and $\alpha$-amylase inhibition of black myrtle is more effective than white myrtle (Table 3). Antioxidants are important to biologists and clinicians due to their protective effects against human body damage (Asparganah and Ariamanesh, 2015). Anti-hyperglycemic effect of $M$. communis leaves extract had been reported on diabetic mice (Benkhayal et al., 2009). In vitro $\alpha$ glucosidase effect of some sample extracts such as Taraxacum officinale, Urtica dioica, Myrtus communis and Viscum album, and some synthetic inhibitors such as Amaryl (glimerid), Betanorm (gliclazide) and Glucobay (acorbose) was investigated by Önal et al. (2005). They found that Myrtus communis showed more effective inhibitory activity (Önal et al., 2005). Myrtle fruits were extracted and given to experimental animals in different doses. It was observed that different doses of extracts decreased blood glucose levels (Demir et al., 2011). Similarly, in a study conducted on rats, it was reported 
that murt leaf extraction decreased blood glucose levels (Baz, 2014). In another study, the effect of mrytle oil on diabetic rabbits was studied and its has proven to be effective on blood glucose levels (Sepici Dincel et al., 2007). In a study in animals with experimentally created diabetes, the ethanolic, aqueous and hydroalcoholic extracts of myrtle leaf were presented to investigate effects on its blood glucose level. According to this research, myrtle leave extracts have been found to reduce blood glucose levels (Panjeshahin et al., 2016).

\section{References}

Alexander, R.J. (1992). "Production and Applications", World Wide Technology. New York, VHC Publishers.

Asgarpanah, J., Ariamanesh, A. 2015. "Phytochemistry and pharmacological properties of Myrtus communis L.", Indian Journal of Traditional Knowledge, 1(1), 8287.

Asif, H.M., Akram, M., Uddin, S., UlHasan, Z., Sami, A., Iqbal, A., Tauseef, A., Bari, A. 2011. "Myrtus communis L. (Pharmacological activity)", Journal of Medicinal Plants Research, 5(26), 62576259.

Baharvand-Ahmadi, B., Bahmani, M., Naghdi, N., Saki, K., Baharvand-Ahmadi, S., Rafieian-Kopaei, M. 2015. "Review on phytochemistry, therapeutic and pharmacological effects of myrtus (Myrtus communis)", Scholars Research Library Der Pharmacia Lettre, 7(11), 160-165.

Baz, H. 2014. "Streptozotocinle indüklenen diyabetli ratlar üzerinde Myrtus communis L. yaprağı su ekstresi etkilerinin araştırılması", Yüksek Lisans Tezi, Atatürk Üniversitesi Sağlık Bilimleri Enstitüsü, Erzurum, 69-70.

Benkhayal, F.A., Musbah, E.G., Ramesh, S., Dhayabaran, D. 2009. "Biochemical studies on the effect of phenolic compounds extracted from Myrtus communis in diabetic rats",
Tamil Nadu Journal of Veterinary Animal and Sciences, 5(3), 87-93.

Bernfeld, P. (1955). "Methods in Enzymology", New York, Academic Press.

Blois, M.S. 1958. "Antioxidant determinations by the use of a stable free radical", Nature, 26, 1199-1200.

Chang, C.C., Yang, M.H., Wen, H.M., Chern, J.C. 2002. "Estimation of total flavonoid content in propolis by two complementary colorimetric methods", Journal of Food and Drug Analysis, 10, 178-182.

Chryssavgi, G., Vassiliki, P., Athanasios, M., Kibouris, T., Michael, K. 2008. “'Essential oil composition of Pistacia lentiscus L. and Myrtus communis L.: Evaluation of antioxidant capacity of methanolic extracts", Food Chemistry, 107, 1120-1130.

Davies, G.J., Henrissat, B. 1995. "Structures and mechanisms of glycosyl hydrolases", Structure, 3(9), 853-859.

Demir, G.M., Gulaboglu, M., Aggul, A.G., Kilic Baygutalp, N., Canayakin, D., Halici, Z., Suleyman, H. 2011. "Antioxidant and antidiabetic activity of aqueous extract of Myrtus Communis L. berries on streptozotocin-induced diabetic rats", IOSR Journal of Pharmacy and Biological Sciences, 11(5), 11-16.

Derwich, E., Benziane, Z., Chabir, R., Taouil, R. 2011. "Characterization of volatiles and evaluation of antioxidant activity of the flower essential oils of Myrtus communis L. from Morocco", Name The Journal, 3(3), 17-23.

Dinis, T.C.P., Madeira, V.M.C., Almeida, L.M. 1994. "Action of phenolic derivates (acetoaminophen, salycilate, and 5aminosalycilate) as inhibitors of membrane lipid peroxidation and as peroxyl radical scavengers", Archives Biochemistry and Biophysics, 315, 161-169.

Durmuş, R.N., Şahin, E., Bireller, S. 2016. "Gestasyonel diyabette hipoglisemik etkili 
bitkilerin kullanımı", Deneysel Tıp Araştırma Enstitüsü Dergisi, 6(11), 3-16.

Ferchichi, H., Salouage, I., Bacha, S., Ben Said, D., Gaies, E., Boussaid, M., Lakhal, M., Klouz A. 2011. "Effect of Myrtus communis L. extracts on attenuation of liver normothermic ischemia-reperfusion injury", Journal of Transplantation Technologies \& Research, doi:10.4172/2161-0991.S3-001.

Güder, A. 2016. "Influence of total anthocyanins from bitter melon (Momordica charantia Linn.) as antidiabetic and radical scavenging agents", Iran Journal of Pharmaceutical Research, 15(1), 301-309.

Johari, H., Nozari, M., Moghtari, M., Zamani, Z., Yazdani, M. 2014. "The effect of myrtus communis extract on liver enzymes and blood biochemical factors in diabetic adult male rats", Zahedan Journal of Research in Medical Sciences, 16, 12-17.

Karaman, Ö., Elgin Cebe, G. 2016. "Diyabet ve Türkiye'de antidiyabetik olarak kullanılan bitkiler", Journal of Faculty of Pharmacy of Ankara University, 40(3), 47-61.

Lebovit, H. 1998. " $\alpha$-Glucosidase inhibitors as agents in the treatment of diabetes", Diabetes Reviewer, 6, 132-145.

McCue, P., Kwon, Y.I., Shetty, K. 2005. "Anti-amylase, anti-glucosidase and antiangiotensin I-converting enzyme potential of selected foods", Journal of Food Biochemistry, 29, 278-294.

Mimica-Dukic, N., Bugarin, D., Grbovic, S., Mitic-Culafic, D., Vukovic-Gacic, B., Orcic, D., Jovin, E., Couladis, M. 2010. "Essential oil of Myrtus communis L. as a potential antioxidant and antimutagenic agents", Molecules, 15, 2759-2770.

Montoro, P., Tuberoso, C.I.G., Piacente, S., Perrone, A., De Feo, V., Cabras, P., Pizza, C. 2006. "Stability and antioxidant activity of polyphenols in extracts of Myrtus communis L. berries used for the preparation of myrtle liqueur", Journal of Pharmaceutical and Biomedical Analysis, 41, 1614-1619.
Naczk, M., Shahidi, F. 2004. "Extraction and analysis of phenolics in food", Journal of Chromatography A, 1054(1-2), 95-111.

Önal, S., Timur, S., Okutucu, B., Zihnioğlu, F. 2005. "Inhibition of $\alpha$-glucosidase by aqueous extracts of some potent antidiabetic medicinal herbs", Preparative Biochemistry and Biotechnology, 35(1), 29-36.

Oyaizu, M. 1986. "Studies on products of browning reactions: Antioxidative activities of product of browning reaction prepared from glucosamine", Japan Journal of Nutrition, 44, 307-315.

Panjeshahin, M.R., Azadbakht, M., Akbari, N. 2016. "Antidiabetic activity of different extracts of Myrtus communis in streptozotocin induced diabetic rats", Romanian Journal of Diabetes Nutrition and Metabolic Diseases, 23(2), 183-190.

Ruch, R.J., Cheng, S., Klaunig, J.E. 1989. "Prevention of cytotoxicity and inhibition of intracellular communication by antioxidant catechins isolated from Chinese green tea", Carcinogenesis, 10, 1003-1008.

Sepici Dincel, A., Gürbüz, I., Çevik, C., Yesilada, E. 2004. "Hypoglycaemic effects of myrtle oil in normal and alloxan-diabetic rabbits", Journal of Ethnopharmacology, 93, 311-318.

Sepici-Dincel, A., Açıkgöz, Ş., Çevik, C., Sengelen, M., Yeşilada, E. 2007. "Effects of in vivo antioxidant enzyme activities of myrtle oil in normoglycaemic and alloxan diabetic rabbits", Journal of Ethnopharmacology, 110, 498-503.

Slinkard, K., Singleton, V.L. 1977. "Total phenol analyses: automation and comparison with manual methods", American Journal of Enology and Viticulture, 28, 49-55.

Tsao, R., Yang, R. 2003. "Optimization of a new mobile phase to know the complex and 
real polyphenolic composition: towards a total phenolic index using high-performance liquid chromatography", Journal

Chromatography, 1018, 29-40.

Wang, H., Nair, M.G., Strasburg, G.M., Chang, Y.C., Booren, A.M., Gray, J.I., Dewitt, D.L. 1999. "Antioxidant and antiinflammatory activities of anthocyanins and their aglycon, cyanidin, from tart cherries", Journal of Natural Product, 62(2), 294-296. 